УДК 346.1

DOI https://doi.org/10.32849/2663-5313.2019.7.5

\title{
Олександр Безух,
}

докт. юрид. наук,

провідний науковий співробітник

відділу правового забезпечення ринкової економіки

Науково-дослідного інституту приватного права і підприємництва

імені академіка Ф. Г. Бурчака Національної академії правових наук України

\section{ПРИВАТНЕ ПРАВО І ПРИВАТНІ ВІДНОСИНИ В УМОВАХ РИНКОВОЇ ЕКОНОМІКИ}

Стаття відображає авторський погляд на приватне право і приватні відносини у сфері ринкової економіки, де індивідуальні майнові і немайнові відносини не мають особистого характеру та підкоряються низиі суспільних явищ, та закономірностей, які не досліджуються иивільним правом України. У статті доводиться, що на відміну від приватних відносин, шо регулюються иивільним правом та характеризуються виключно розсудом (волею) та диспозитивністю сторін, приватні ринкові відносини містять додаткові чинники, які не враховуються в иивільноправовому регулюванні, а саме: наявність конфлікту між суб'єктами ринку щодо їхніх економічних інтересів, який керується та перманентно вирішується за допомогою економічної конкурениії (саморегулювання) або владними приписами держави з міркувань суспільних інтересів та з проблем спотворення економічної конкурениї; наявність суспільних інтересів на ринку, що забезпечуються імперативними приписами держави, які зобов'язані виконувати всі учасники приватних економічних відносин; наявність економічних закономірностей (наприклад, закон попиту і пропозииї, економічна конкурениія, захист споживачів як асиметрична відповідь держави на прояви економічної влади), які забезпечують баланс i саморегулювання ринку (суспільний інтерес) та підтримуються правовими засобами; наявність феномену економічної влади, через який певні суб'єкти ринку можуть диктувати іншим учасникам ринкових відносин умови обороту товарів на ринку або здійснювати інший вплив на економічну поведінку учасників ринку. Це потребує іншого окремого режиму правового регулювання та визначення іншого правового статусу учасників ринкових відносин. Автором робиться висновок, що відмінність між приватними особистими та ринковими відносинами полягає в тому, що в приватних иивільних відносинах головним є забезпечення особистої волі та диспозитивності сторін у реалізації приватних прав, у приватних ринкових відносинах головним є забезпечення виконання економічної функиї кожного суб'єкта права як учасника таких відносин. Констатується, що мета правового регулювання в приватних иивільних відносинах і приватних економічних відносинах є різною. У першому випадку ие забезпечення реалізачії особистих прав, у другому - ие забезпечення стабільності ринкових відносин і ринку як системи, забезпечення економічного добробуту суспільства в иілому.

Ключові слова: приватне право, приватні відносини, економічна конкуренція.

Постановка проблеми. 3 розвитком громадянського суспільства в Україні на новий рівень поставлені дослідження в галузі права, зокрема, місця та значення приватного права та його співвідношення з публічним правом. Повністю підтримуючи погляди українських цивілістів щодо регулювання особистих майнових та немайнових відносин серед приватних фізичних осіб та певних приватних юридичних осіб, зазначимо, що такі підходи не можуть бути тотожно застосовані до суб'єктів господарювання в умовах ринкової економіки. Ототожнення узагальненого у ст. 1 ЦК України поняття цивільних відносин як особистих майнових і немайнових відносин, що формуються на засадах юридичної рівності і вільного волевиявлення
3 усім приватним правом [1, с. 8], на думку автора, є помилковим.

Аналіз публікацій. Незважаючи на те, що дослідженню приватного права і відносин присвячені чисельні праці, серед яких «Доктрина приватного права України» за заг. редакцією Н.С. Кузнецової, «Розвиток приватного права України» Р.А. Майданика та багато інших, закономірності приватних відносин у сучасних ринкових умовах не досліджувалися.

Метою статті є дослідження закономірностей приватних економічних відносин в умовах ринкової економіки та розуміння приватного права в країнах з розвинутою ринковою економікою. 
Виклад основного матеріалу дослідження. Ключовим для розуміння необхідності різних підходів до правового регулювання відносин приватних фізичних та окремих приватних юридичних осіб та відносин за участю суб'єктів господарювання є розуміння та розмежування для застосування: 1) поняття особистих (індивідуальних) відносин, які застосовуються в цивільному приватному праві з часів Римського права, та 2) ринкових відносин, поняття яких у цивільному праві (так само як і в приватному праві часів Риму) не згадується, коли всі суб'єкти діють в умовах ринку та його закономірностей.

Особистість - відображення соціальної природи людини, розгляду її як індивідуальності та суб'єкта соціокультурного життя, що розкривається в контекстах соціальних відносин, спілкування і предметної діяльності, соціально зумовлена система психічних якостей індивіда, що визначається залученістю людини до конкретних суспільних, культурних, історичних відносин [2].

Усім зрозуміло, що суб'єкти господарювання не можуть розглядатися у контексті природи людини, яка характеризується системою психічних якостей індивіда. Тому поняття особистості та особистих (індивідуальних) відносин в цивільному праві, що притаманно фізичним особам, не може бути повною мірою застосовано до юридичних осіб, тим більше як суб'єктів ринку в умовах суспільного характеру виробництва. Будьяка воля пов'язана з особою (індивідом), але в ринковій економіці загальноприйнятою $є$ думка, що прийняття рішень відбувається (повинне відбуватися) у зв'язку з дією ринкових сил, а не волі сторін. Тому автором розділяється розуміння цивільних відносин як особистих і ринкових відносин, де дії визначаються не лише волею, а насамперед дією ринкових сил та закономірностей.

Другим ключовим пунктом $є$ розуміння відносин за участю суб'єктів господарювання як економічних ринкових відносин. Ринкові відносини - це відносини і зв'язки, які складаються між продавцями і покупцями в процесі купівлі продажу товарів. Держава також виступає найбільшим продавцем та покупцем товарів на ринку. Ці відносини, оскільки вони $\epsilon$ приватними за змістом, підкоряються певній низці економічних законів та суспільних закономірностей, які жодним чином не враховуються в цивільному праві, але підлягають урахуванню у правовому регулюванні відповідних приватних відносин як ринкових за допомогою спеціальних правових інструментів. Продавець може виступати як виробник, що вводить товар у господарський ринковий обіг, та як підприємець, який займається роз- повсюдженням товарів. На ринку кожний учасник відносин виконує певну функцію, а іноді й не одну. Наприклад, споживач є «арбітром» економічної конкуренції. Суб'єкт господарювання може бути як підприємцем, так і споживачем. Збій у виконанні певних функцій може призводити до руйнування відносин як ринкових.

Усі відносини на ринку підкоряються суспільному розподілу праці. Усі учасники (суб'єкти) виконують різні економічні функції та внаслідок цього мають відмінні економічні інтереси, які конфліктують між собою. Рух товару на ринку часто-густо знеособлений на відміну від особистих відносин в цивільному праві, оскільки головним чинником є певні економічні закономірності та функції, а не особи учасників відносин. Тобто фактичні відносини та зв'язки за участю суб'єктів господарювання в умовах ринку можуть суттєво принципово відрізнятися від особистих майнових і немайнових відносин за участю лише фізичних осіб та визначаються тією економічною функцією, яку виконуе учасник відносин в умовах ринку.

Незважаючи на те, що рішення щодо встановлення правових економічних відносин в умовах ринку є децентралізованими, тобто такими, що приймаються незалежними суб'єктами або їх групами, сам ринок є соціально-економічною системою, яка передбачає наявність суспільних інтересів. Зміст суспільних інтересів конкретизується в конкретних нормах права. Наприклад, відповідно до ч. 1 ст. 1 Закону України «Про загальну безпечність нехарчової продукції» суспільні інтереси - безпека життя та здоров'я людей, безпечні умови праці, захист прав споживачів (користувачів), захист довкілля [3]. Ці інтереси забезпечуються спеціальними правовими інструментами - правовими приписами, які зобов'язують учасників ринку у приватних відносинах діяти у порядку, визначеному правовою нормою.

Другим прикладом наявності суспільних інтересів на ринку та у приватних відносинах, які на ньому відбуваються, є регулювання відносин, що виникають у зв'язку з прийняттям технічних регламентів і передбачених ними процедур оцінки відповідності, їх застосуванням стосовно продукції, яка вводиться в обіг, надається на ринку або вводиться в експлуатацію в Україні. Технічні регламенти можуть створювати перешкоди у встановленні правових економічних відносин між учасниками ринку - «бар'єри в торгівлі». Згідно 3 п. 2.2 Угоди про бар'єри у торгівлі технічні регламенти не можуть розроблятися, прийматися і застосовуватися у спосіб, метою або наслідком якого є створен- 
ня невиправданих перепон для міжнародної торгівлі. Для цього технічні регламенти не повинні мати більш обмежувального впливу на торгівлю, ніж це є необхідним для виконання законних завдань, 3 урахуванням ризиків, які б виникли в результаті їх невиконання. Такими законними завданнями $\epsilon$, inter alia: вимоги національної безпеки; запобігання шахрайським діям; захист життя або здоров'я людини, тварин або рослин, а також захист навколишнього середовища. Для оцінки таких ризиків до уваги беруться, inter alia, такі елементи: наявна наукова та технічна інформація, відповідна технологія обробки або очікуване кінцеве використання товарів [4].

Таким чином, вимоги національної безпеки; запобігання шахрайським діям; захист життя або здоров'я людини, тварин або рослин, а також захист навколишнього середовища можуть передбачати та передбачають встановлення імперативних перешкод та обмежень в реалізації приватних відносин і інтересів, не змінюючи їхню сутність як приватних. Але в таких приватних відносинах не все залежить від волі учасників відносин. Сам принцип свободи договору, а саме можливість укладати будь-які договори та визначати їх умови на свій розсуд, є обмеженим вищезазначеними економічними та суспільними чинниками. Зміст принципу свободи договору в особистих відносинах і в приватних ринкових відносинах є різним. У своїх приватних відносинах учасники зобов'язані або вимушені підкорятися волі (приписам) держави або інших суб'єктів правового регулювання, а також тих осіб, які домінують на ринку.

Окремо необхідно зупинитися на питаннях безпеки. Згідно із Законом України «Про основи національної безпеки України» національна безпека - захищеність життєво важливих інтересів людини і громадянина, суспільства і держави, за якої забезпечуються сталий розвиток суспільства, своєчасне виявлення, запобігання і нейтралізація реальних та потенційних загроз національним інтересам у сферах правоохоронної діяльності, боротьби з корупцією, прикордонної діяльності та оборони, міграційної політики, охорони здоров'я, охорони дитинства, освіти та науки, науково-технічної та інноваиійної політики, культурного розвитку населення, забезпечення свободи слова та інформаційної безпеки, кібербезпеки та кіберзахисту, соціальної політики та пенсійного забезпечення, житлово-комунального господарства, ринку фінансових послуг, захисту прав власності, фондових ринків $і$ обігу цінних паперів, податково-бюджетної та митної політики, торгівлі та підприємницької діяльності, ринку банківських послуг, інвестищійної політики, ревізійної діяльності, монетарної та валютної політики, захисту інформаиії, лічензування, промисловості та сільського господарства, транспорту та зв'язку, інформачійних технологій, енергетики та енергозбереження, функиіонування природних монополій, використання надр, земельних та водних ресурсів, корисних копалин, захисту екологї і навколишнъого природного середовища та інших сферах державного управління у разі виникнення негативних тенденцій до створення потенційних або реальних загроз національним інтересам [5].

Автором курсивом виділено сфери діяльності, які мають безпосереднє відношення до ринків та ринкових відносин. Їх набагато більше, ніж інших сфер діяльності, що входять до національної безпеки.

Окрім цього існує ще економічна безпека. Економічна безпека - це такий стан національної економіки, який дає змогу зберігати стійкість до внутрішніх та зовнішніх загроз і здатний задовольняти потреби особи, сім'ї, суспільства та держави.

Загрози економічній безпеці України це сукупність наявних та потенційно можливих явищ і чинників, що створюють небезпеку для реалізації національних інтересів у економічній сфері. Вичерпний перелік цих явищ і чинників законодавством не визначено, лише встановлено, що складниками економічної безпеки є: макроекономічна, фінансова, зовнішньоекономічна, інвестиційна, науково-технологічна, енергетична, виробнича, демографічна, соціальна, продовольча безпека [6].

Приватні інтереси, як життєво важливі інтереси людини і громадянина, $є$ важливим складником національної безпеки, але вони є лише певним складником, який підкоряється загальному, що включає інтереси суспільства і держави (публічні інтереси). Особисті відносини стосуються лише осіб, які в них вступили, та не повинні впливати на інших осіб. Наявність публічних інтересів у відносинах суб'єктів ринкових відносин не змінює приватного характеру таких відносин, але підпорядковує такі відносини вимогам публічного господарського правопорядку. Приватні економічні відносини втрачають свій особистісний характер, оскільки в умовах ринку можуть так чи інакше зачіпати інтереси інших учасників та впливати на рівновагу ринку, тобто на економічну безпеку i національні інтереси. Наприклад, укладення суб'єктами господарювання приватних договорів щодо реалізації товару породжує таке публічне явище, як економічна конкуренція. 
Приділення уваги в оцінці та характеристиці приватних відносин переважно диспозитивності та рівності сторін як головних чинників, без урахування інших суттєвих чинників часто-густо вводить в оману та самооману щодо справжнього характеру таких відносин. По-перше, сучасний ринок це система, а приватні економічні правові відносини можуть існувати лише в межах такої системи та є залежними від такої системи. По-друге, в приватних ринкових відносинах, колі відкинути економічні складнки, завжди існує феномен влади (не йдеться про державну владу), коли одні учасники ринкових відносин можуть мати та мають владу над іншими учасниками. Як слушно зазначив Г.В. Атаманчук, владою в широкому сенсі є взаємозв'язки між особами, за яких одні суб'єкти в силу різноманітних причин, умов i факторів підкоряються інтересам і волі інших осіб або створених суспільних інститутів: звичаям, традиціям, релігіям, моралі, праву і таке інше [7]. У ринкових відносинах діє економічна влада, коли певні суб'єкти господарювання в силу економічного стану, доступу до матеріальних ресурсів, реклами, наявності певних ексклюзивних благ (наприклад, патенти, промислові зразки, технології та ін.) можуть диктувати власну волю іншим суб'єктам ринкових відносин та впливати на їхню поведінку (прийняття тих чи інших рішень в тому числі на невигідних для суб'єкта умовах).

Також суб'єктами влади є органи державної та місцевої влади або інші суб'єкти економічної діяльності, в тому числи держава, які спроможні домінувати на ринку або впливати на економічну поведінку їі учасників.

Влада у ринкових відносинах реалізується у власних економічних інтересах, які є різними, а іноді діаметрально протилежними у різних учасників таких відносин. Об'єктивно різні інтереси учасників ринку породжують конфлікт у відносинах, та вся система реальних приватних економічних відносин існує в умовах фактичного конфлікту економічних інтересів та юридичних прав різних учасників ринку. Одним із головних завдань правового регулювання є усунення конфліктів між учасниками відносин. Цивільне право України, яке претендує на домінуюче положення у регулюванні всіх різновидів приватних відносин, не дає відповіді на питання: які конфлікти існують у ринкових приватних відносинах (загальні та окремі для певних сфер) та які правові інструменти необхідно застосовувати для їх подолання, окрім судового захисту порушених прав та інтересів.

$\mathrm{y}$ таких умовах постає завдання визначення змісту приватного права в умовах рин- кових економічних відносин. «У вітчизняній юридичній науці приватне право визначається як сукупність правил та норм, що стосуються визначення статусу і захисту інтересів окремих осіб, які не є фігурантами держави, не перебувають у відносинах влади і підпорядкованості один одному, рівноправно і вільно встановлюють собі права і обов'язки у відносинах, що виникають за їхньою ініціативою» [1, с. 166-167].

Не заперечуючи наведені підходи в особистих відносинах, спробуємо дослідити, чи відповідає такий підхід реаліям сучасних економічних відносин. Аналіз чинного законодавства свідчить, що з метою забезпечення стабільності ринкових відносин держава імперативними приписами покладає на суб'єктів господарювання певні зобов'язання. Наприклад, згідно зі ст. 6 Закону України «Про захист прав споживачів» виробник (виконавець) зобовязаний забезпечити технічне обслуговування та гарантійний ремонт продукції, а також іï̈ випуск і поставку для підприємств, що здійснюють технічне обслуговування та ремонт, у необхідному обсязі та асортименті запасних частин протягом усього строку її виробництва, а після зняття з виробництва - протягом строку служби, в разі відсутності такого строку - протягом десяти років [8]. Тобто незалежно від волі приватної особи не неї законом покладено додаткове зобов'язання по відношенню до інших учасників приватних відносин, що не узгоджується зі змістом ст. 1, 6 ЦК України.

Іншим прикладом відсутності особистої волі в приватних правочинах є феномен публічних договорів. Незважаючи на те, що ст. 633 ЦК України задекларовано поняття публічного договору для певних сфер діяльності, дослідження цього явища 3 позицій цивільного права не здійснюється. Зрозуміло, що поняття публічного є об'єктивним антагоністом поняттю приватного. В усіх приватноправових працях поняття публічного і приватного чомусь протиставляються, хоча, як зазначалося вище, приватні інтереси об'єктивно є частиною публічних явищ. Публічні договори укладаються між приватними особами, але вони позбавлені більше чи менше свободи волі та рівності у визначенні умов таких відносин. Коли ми кажемо, що свобода договору є принципом, як це визначено ст. 3 ЦК України, то принцип не може мати різний зміст в однакових приватних відносинах. Насправді зміст цього принципу в особистих приватних відносинах і ринкових приватних відносинах $є$ різним [9].

Взагалі, сфера публічних договорів є набагато ширшою, ніж це передбачено ЦК України. Наприклад, ст. 26 Закону України «Про 
зерно та ринок зерна в Україні» встановлено, що договір складського зберігання зерна $є$ публічним договором, типова форма якого затверджується Кабінетом Міністрів України [10]. Тобто ознакою публічного договору між приватними особами є не воля сторін, а імперативні приписи нормативного акта, який і визначає умови договору між приватними особами, їхні права на розсуд держави.

Саме вимоги національної безпеки, запобігання шахрайським діям, захист життя або здоров'я людини, тварин або рослин, захист навколишнього середовища, а також забезпечення життєво важливих інтересів людини спонукають державу корегувати певні види приватних відносин залежно від негативних чинників, що на них впливають. Залежно від сфери приватних відносин, зокрема сфери ринкових відносин, такі чинники є різними, що породжує різні режими правового регулювання, тобто застосування в різних сферах різних правових інструментів, різного порядку виникнення та формування конкретних прав і обов'язків, їх здійснення, юридичної відповідальності та санкцій, дії єдиних принципів та загальних положень тощо. Саме специфічність юридичного режиму пов'язують iз характеристикою галузі права [11, с. 172].

Загальноприйнятою є думка, що «правовий режим сфери приватного права являе собою цілісну систему регулятивного впливу, яка створює загальнодозвільний тип регулювання майнових та особистих немайнових відносин, заснований на юридичній рівності, вільному волевиявленні, майнової самостійності їх учасників, забезпечує можливість самовизначення і власних активних дій, спрямованих на виникнення та здійснення суб'єктивних прав і обов'язків у межaх встановлених договором або законом, з метою досягнення певних приватних цілей та інтересів» [12].

Разом із тим аналіз сучасних ринкових приватних відносин свідчить, що, окрім загальнодозвільного типу регулювання відносин, залежно від специфіки сфери правового регулювання, застосовується і загальнозаборонний тип регулювання, а в межах загальнодозвільного типу регулювання застосовуються різні, відмінні між собою режими правового регулювання, коли разом iз дозволами приписами встановлюються позитивні зобов'язання.

Наприклад, Закон України «Про захист економічної конкуренції» забороняє всі приватні ринкові відносини, що можуть призвести або призводять до спотворення, недопущення або порушення економічної конкуренції. Це загальне правило поширюється на всі приватні ринкові відносини, але жодним чином не стосується особистих приватних майнових відносин. Закон України «Про захист прав споживачів» забороняє встановлення будь-яких переваг, застосування прямих або непрямих обмежень прав споживачів, які перебувають у приватних відносинах із суб'єктами господарювання. Порушення правових заборон тягне передбачену законом юридичну відповідальність. Необхідно також підкреслити, що в межах загальнодозвільного типу правового регулювання особистих приватних відносин і ринкових приватних відносин застосовуються різні режими правового регулювання. Наприклад, у ринкових договірних відносинах застосовується правовий режим публічного договору, який встановлюе правові зобов'язання учасників приватних відносин, від яких, усупереч ст. 6 ЦК України, такі учасники не можуть відступити, правові режими захисту економічної конкуренції, технічного регулювання введення в обіг та обороту товарів на ринку. Це пов'язано якраз із суспільними інтересами у приватних відносинах і наявністю різних сфер і центрів впливу на них.

Автори монографії «Доктрина приватного права України» вважають такий підхід прикладом «надмірно спрощеного розуміння системи права як сукупності правових утворень $з$ невизначено великою кількістю юридичних центрів, поділених не за дихотомічним правилом - публічного і приватного права, а за принципом автономності сфери правового регулювання, що відповідає поняттю галузі законодавства [1, с. 166]. 3 таким підходом не можна погодитися, оскільки він не відповідає правовим реаліям. Як вже зазначалося, галузева належність права визначається насамперед специфічністю юридичних режимів правового регулювання, а не дихотомічним поділом на приватне і публічне. Також необхідно звернути увагу на поняття цілісності правового впливу. Як можливо уявляти регулювання приватних ринкових відносин, наприклад, без публічних правових заборон щодо порушень економічної конкуренції або публічних зобов'язань суб'єктів господарювання виконувати вимоги технічних регламентів під час введення товару в обіг та його обороту, щоб забезпечити права споживачів? Конкурентне право є складовою частиною договірного права в умовах ринку, регулює відносини між приватними особами, але воно відокремлено від сучасного приватного права. Може, необхідно припинити рецепцію в сучасне приватне право принципів римського права, а дивитися на сучасні правові реалії та закономірності? 
Водночас приватне право в країнах континентальної Європи «розглядається як система джерел права, що регулюють відносини між їх учасниками як приватними особами» [1, с. 166]. Саме правовий статус особи $€$ визначальним у регулюванні відносин. Як слушно зазначив С.С. Алексєєв, хоча галузеві методи і механізми, що їм відповідають, за своїми початковими елементами побудовані на двох простих початках - централізованому і диспозитивному регулюванні, останні в кожній галузі у поєднанні зі всією сукупністю способів правового впливу (дозволами, заборонами, позитивним зв'язуванням) отримують своєрідний вираз. Це відображається насамперед у правовому статусі суб'єктів - головній рисі кожної основної галузі під кутом зору властивих їй методу і механізму регулювання [11, с. 173].

Необхідно констатувати, що правовий статус суб'єкта господарювання відрізняється від правового статусу фізичної особи в однакових, наприклад, договірних відносинах. В умовах ринкової економіки конкурентне право є частиною договірного права, але для регулювання особистих приватних відносин воно не застосовується. Правовий статус учасника приватних ринкових відносин визначається насамперед тією функцією, яку він виконує як учасник відповідних відносин в ринковій системі, що визначає мету правового регулювання та правові інструменти, які застосовуються. За таких умов було би помилково говорити, наприклад, про суперечність певних норм ЦК України та ГК України, оскільки мета та завдання регулювання особистих немайнових і майнових відносин та сучасних ринкових відносин $є$ різними. Наведені кодекси будуються на різних принципах правового регулювання. За таких умов 3 яких підстав вимагають тотожності правових інструментів у різних механізмах правового регулювання?

\section{Висновки}

У приватних цивільних відносинах, які фактично мають особистий характер (тобто регулюють відносини між певними особами без урахування наявності економічних інтересів і прав інших осіб), головними чинниками є воля особи та її особистий економічний інтерес, які вирішуються на основі диспозитивності сторін, тоді як головними чинниками приватних економічних відносин у ринковій сфері є:

воля осіб, які на свій розсуд вступають у відносини або відмовляються від них в тому числі внаслідок встановлених імперативних правил у певній сфері відносин (принцип автономії прийняття рішень); наявність конфлікту між суб'єктами ринку щодо їхніх економічних інтересів, який керується та перманентно вирішується за допомогою економічної конкуренції (саморегулювання) або владними приписами держави 3 міркувань суспільних інтересів та з проблем спотворення економічної конкуренції;

наявність суспільних інтересів на ринку, що забезпечуються імперативними приписами держави, які зобов'язані виконувати всі учасники приватних економічних відносин;

наявність економічних закономірностей (наприклад, закон попиту і пропозиції, економічна конкуренція, захист споживачів як асиметрична відповідь держави на прояви економічної влади), які забезпечують баланс і саморегулювання ринку (суспільний інтерес) та підтримуються правовими засобами;

наявність феномену економічної влади, в силу якого певні суб'єкти ринку можуть диктувати іншим учасникам ринкових відносин умови обороту товарів на ринку або здійснювати інший вплив на економічну поведінку учасників ринку.

Для регулювання особистих приватних відносин та ринкових приватних відносин застосовуються різні режими правового регулювання.

У разі вступу учасників ринкових відносин у правові приватні договірні відносини вони об'єктивно породжують публічні явища (наприклад, економічну конкуренцію, стан національної та економічної безпеки, охоронні відносини та ін.) та певні юридичні наслідки, які неможливі у разі здійснення особистих майнових або немайнових відносин. Правові наслідки у приватних відносинах настають у разі суперечності вимогам національної та економічної безпеки, економічної конкуренції, вимогам технічного регулювання, прав споживачів, екологічної безпеки та інших випадках.

Відмінність між приватними особистими та ринковими відносинами полягає в тому, що в приватних цивільних відносинах головним є забезпечення особистої волі та диспозитивності сторін в реалізації приватних прав, у приватних ринкових відносинах головним є забезпечення виконання економічної функції кожного суб'єкта права як учасника таких відносин. Необхідно констатувати, що мета правового регулювання в приватних цивільних відносинах і приватних економічних відносинах $є$ різною. У першому випадку - це забезпечення реалізації особистих прав, у другому - це забезпечення стабільності ринкових відносин і ринку як системи, забезпечення економічного добробуту суспільства в цілому. 


\section{Список використаних джерел:}

1. Правова доктрина України: у 5 т. Т. 3: Доктрина приватного права України / Н.С. Кузнецова, Є.О. Харитонов, Р.А. Майданик та ін. ; за заг. ред. Н. С. Кузнецової. Харків : Право, 2013.

2. Особистість. URL. https://uk.wikipedia. org/wiki/\% D0\%9E\%D1\%81\%D0\%BE\%D0\% B1\%D0\%B8\%D1\% 81\%D1\%82\%D1\%96\%D1\%81\% D1\%82\% D1\%8C. (дата звернення: 10.05.2019).

3. Про загальну безпечність нехарчової продукції : Закон України від 02.12.2010 № 2736-VI. Відомості Верховної Ради Украӥни. 2011. № 22. Ст. 145.

4. УГода про технічні бар'єри у торгівлi. URL. https://zakon.rada.gov.ua/laws/ show/981_008 (дата звернення: 11.04.2019).

5. Про основи національної безпеки України : Закон України від 19.06.2003 № 964-IV. Вiдомості Верховної Ради Украйни. 2003. № 39. Ст. 351.

6. Про затвердження методичних рекомендацій щодо розрахунку рівня економічної безпеки України : наказ Міністерства економічного розвитку і торгівлі України від 29.10.2013 № 1277. URL. https://zakon.rada.gov. ua/rada/show/v1277731-13 (дата звернення: 19.05.2019)

7. Атаманчук Г.В. Теория государственного управления : учебник. Москва : изд-во «Омега Л», 2014. C. 21

8. Про захист прав споживачів : Закон України від 12.05.1991 № 1023-ХII. Відомості Верховної Ради УРСР. 1991. № 30. Ст. 379.

9. Безух О.В. Господарський (комерційний) та цивільний обороти: сутність та відмінності в умовах ринкової економіки. Приватне право і підприємниитво: збірник наукових праць. 2016. Вип. 16. Київ : Науково-дослідний інститут приватного права і підприємництва ім. академіка Ф. Г. Бурчака НАПрН України. С. 35-41.

10. Про зерно та ринок зерна в Україні : Закон України від 04.07.2002 № 37-IV. Відомості Верховної Ради України. 2002. № 35. Ст. 258.

11. Алексеев С. С. Общая теория права: учебник. Москва : ТК Велби, изд-во Проспект, 2008. 275 с.

12. Правова система України: історія стан та перспективи: у 5-т. Т. 3: цивільно-правові науки. Приватне право / за заг. ред. Н.С. Кузнецової. Харків : Право, 2008. С. 34.

The article reflects the author's view on private law and private relations in the sphere of market economy, where individual property and non-property relations are not personal in nature and are subject to a number of social phenomena and laws that are not investigated by the civil law of Ukraine. The article argues that, unlike private relations governed by civil law and characterized exclusively by discretion (will) and dispositivity of the parties, private market relations contain additional factors that are not taken into account in the civil law regulation, namely: the existence of a conflict between the subjects of the market in relation to their economic interests, which is guided and permanently resolved by means of economic competition (self-regulation) or state imperatives of the public interest and of the problems of distortion of e competition competition; presence of social interests on the market, provided by imperative requirements of the state, which are obliged to fulfill all participants of private economic relations; the existence of economic laws (for example, the law of supply and demand, economic competition, consumer protection as an asymmetric response of the state to the manifestation of economic power) that ensure the balance and self-regulation of the market (public interest) and supported by legal means; the presence of the phenomenon of economic power, by virtue of which certain market actors can dictate to other market participants the conditions for the circulation of goods in the market or have a different influence on the economic behavior of market participants. This requires another separate legal regime and the definition of another legal status of market participants. The author concludes that the distinction between private personal and market relations lies in the fact that in private civil relations the main thing is to secure personal freedom and dispositivity of the parties in the realization of private rights, in the private market relations the main thing is to ensure the fulfillment of the economic function of each subject as party to such relationships. It is stated that the purpose of legal regulation in private civil relations and private economic relations is different. In the first case, it is the provision of the realization of personal rights, in the second, it is ensuring the stability of market relations and the market as a system, ensuring the economic well-being of society as a whole.

Key words: private law, private relations, economic competition. 